\title{
The Impact of Talent Management on Non-managerial Employees' Retention in the Private Commercial Banking Sector of Sri Lanka
}

\author{
W.K.A. Fernando ${ }^{1}$ \& K.A.M.S. Kodisinghe ${ }^{2}$ \\ 1,2 Department of Business Management \\ Faculty of Business Studies and Finance, \\ Wayamba University of Sri Lanka, \\ Kuliyapitiya \\ SRI LANKA \\ 95anuththara@gmail.com ${ }^{1}$, kodisinghe@wyb.ac.lk²
}

\begin{abstract}
The functioning and long term survival of any organizations highly depends on several factors. Attracting and retaining the best talented employees is a key factor to ensure the accomplishment of organizational goals. Nowadays, most of organizations pay little attention on the retention of employees than attracting them. As a significant determinant for achieving organization's goals, this study is to discuss the impact of Talent management on Non managerial employee retention in private commercial banking sector, Western province of Sri Lanka. According to the previous studies researchers proved that generally private sector employees enjoy more financial and non-financial benefits rather than state sector banking employees. But employee retention in private commercial banking sector lower than state banking sector. This reason was root factor to study the employee retention in private commercial banking sector. Further this study was focused on Non managerial employees in private commercial banks since they are the drivers of daily operations of banks. Further, their employee turnover is greater than Managerial level employees. The main objective of this study is to investigate the impact of Talent management on Non managerial employee retention. The study problem is to identify the impact of Talent management on Non managerial employee retention in private commercial banking sector of Western province in Sri Lanka. The data were collected by distributing a structured questionnaire from the convenient select sample of 375 of non-managerial employees in private commercial banks, Western province of Sri Lanka. The data were presented and analyzed using SPSS version 20.0. The Pearson product movement correlation analysis and least square linear regression analysis analyzed the data over which the hypothesis were tested. The findings of the study indicated that Talent management function positively correlated with non-managerial employee retention in private commercial banks and based on study findings and previous literatures study concluded that Talent management is a significant factor that considerably effect on employee retention.
\end{abstract}

Keywords:- Employee Retention, Non- Managerial Employees, Private Banking Sector, Talent Management 


\section{INTRODUCTION}

The Banking sector in Sri Lanka is the foundation of county's financial system and nowadays both private and government commercial banks represents $48.1 \%$ contribution to the county's financial system. The banking sector was originated in Sri Lanka when the country was under the colony of British. However today, banking sector of Sri Lanka comprises with 25 licensed commercial banks including 12 branches of foreign banks and 7 licensed specialized banks. Western province of Sri Lanka can be identified as the most economically developed and populated part and more than $50 \%$ of contribution to the GDP represented by Western province. This study has focused 15004 of Non managerial employees in private commercial banks of Western province in Sri Lanka. .

According to Walker (2001) in today's competitive business world attracting and retaining the best talented employees are the most challengeable issue that every manager faces. Nowadays employees in the organizations expect variety of things rather than only salary. Employees are satisfied when they have better working environment, good stream relations, career growth opportunities, recognition, rewards etc. As well as today's most of the organizations pay little attention on retaining employees rather than attracting them. As a result organizations have to incur more time and cost to attract suitable freshers and after that they pay little attention to retain and manage their results. Accordingly organizations are suffering a problem of employee turnover. Both private and government banks are also suffering a problem of employee turnover and this is a most common issue specially in private commercial banking sector in Sri Lanka. Since the banking sector shows the high employee turnover due to various reasons, banks are in the process of implementing talent management practices such as talent acquisition, talent development and use different compensation strategies to satisfy their employees. According to the view of Healthfield, M. (2019) employee recruitment and investment on training and development are dimensions of talent management. By analyzing the data relating to the employee recruitment and investment on training, it is noted that all commercial banks are highly involve in talent management practices. They increase cost and time for the progression of their employees year by year.

It is significant to study the impact of implementing talent management practices on employee retention in private commercial banking sector. Accordingly it is proved that there is impact of talent management on employee retention. Hence researcher attempts to investigate the impact of talent management practices on nonmanagerial employee retention in private commercial banking sector of Western province in Sri Lanka. In Sri Lankan context there is empirical and knowledge gap about the impact of talent management on nonmanagerial employee retention in 
private commercial banking sector. Therefore this study conducted to investigate whether there is a relationship between talent management and non-managerial employee retention in private commercial banking sector and main objective of this study is to investigate the impact of talent management on non-managerial employee retention. According to the view of Cobb (2008), competitive market place continues to make talent since it is the primary drive for organizational success. Indeed organizations should establish its core competencies in talent attraction, development and employee retention not just the envy of its rivals, but it guarantees the stability and success of organizations (Silvia, K. 2016).

Talent Management is a conscious, deliberate approach adopted by the organizations to attract, develop and retain people who possess right competencies, attitudes and aptitude to meet the strategic objectives of the organizations (Stockly, 2007). Employee retention is concerned with keeping or encouraging employees to remain in an organization for a maximum period of time (Kossavi, et al., 2016). Herman \& Gioia (2001), indicated losing employees is a cost and that directly or indirectly affect for the business as it causes instability in work force, results in reduced productivity, lower effectiveness and which leads to reduce employee morale also. Hence employee retention is the most significant factor and Silvia, K. (2013) has found talent management practices stimulate employee retention specially in banking sector.
The rationale behind this is employees who are provided opportunity for career development and professional developments are likely to buildup long-term relation with the organizations. If the employees are satisfied with the organization's culture, policies and procedures in this case employees will never find another place for new careers. In this situation organization's employee retention will be protected. Accordingly employee talent management can be recognized as an employee retention strategy.

\section{METHODS}

The objective of the present study was to investigate the impact of talent management on employee retention. To accomplish that purpose researcher has used two variables independent variable and dependent variable. The independent variable is associated with four dimensions as talent acquisition, talent development, succession planning (Kigo, 2016) and rewards and compensation strategies (Cheng, et al., 2017).The following figure shows the theoretical framework of the study. 


\section{Talent Management (TM) \\ Talent Acquisition (TA) \\ Talent Development (TD) \\ Succession Planning (SP) \\ Rewards \& Compensation Strategies (RCS)}

\section{Employee Retention (ER)}

\section{Figure 1: Schematic diagram of theoretical framework}

In this study researcher has used descriptive research procedure and 375 non managerial employees in private commercial banks were selected as the sample through convenient sampling method. As well as the collection of data was done through a structured questionnaire with five points likert scale from strongly disagree to strongly agree. The questionnaire was consisted with 39 questions under five variables (TA, TD. RCS, SC and ER). Both instruments reported high internal consistency (Cronbach Alpha values: Talent Management scale $=0.803$ and Employee Retention scale = 0.792). The cross-sectional study gathered data through a field survey. The data analysis of this study involved descriptive statistics for measuring demographic factors. Correlation analysis and regression analysis used to investigate the impact of talent management on employee retention and to identify the association between those two variables.

\section{RESULTS}

According to the results of demographic factors, $58.7 \%$ of gender dominated by male, age category $42.4 \%$ was dominated by age group 40- 49.under the category of service period $44.8 \%$ were dominated by 4-6 year service period and based on the administrative job title $80.3 \%$ were on the executive category and $85.6 \%$ were married respondents. The proposed associations in the research model were tested using Pearson correlation analysis and following table 1 shows the results of the analysis.

Table 1: Pearson correlation

\begin{tabular}{|l|l|l|l|l|l|}
\hline & ER & TA & TD & RCS & SP \\
\hline $\begin{array}{l}\text { Emloyee } \\
\text { Retention }\end{array}$ & 1 & .691 & .522 & .558 & .266 \\
\hline $\begin{array}{l}\text { sig.(2 } \\
\text { tailed) }\end{array}$ & & .000 & .000 & .000 & .000 \\
\hline $\mathrm{N}$ & 375 & 375 & 375 & 375 & 375 \\
\hline
\end{tabular}

Source: Survey data,2020

According to the results of Pearson correlation analysis it represents all factors are positively correlated with employee retention. Pearson correlations were $0.691,0.522,0.558$ and 0.266 for TA, TD, RCS and SC respectively. All $\mathrm{p}$ values regarding 
to all variables are less than significance level (Sig. level is 0.05).Accordingly correlations between TM functions and ER can be recognized as statically significant.
The table 2 shows the coefficient determination of the model.

Table 2: Goodness of the fitted model

\begin{tabular}{|c|c|c|c|c|}
\hline $\mathbf{R}$ & R square & $\begin{array}{c}\text { adjusted R } \\
\text { square }\end{array}$ & $\begin{array}{c}\text { std. error of the } \\
\text { estimate }\end{array}$ & $\begin{array}{c}\text { Durbin } \\
\text { Watson }\end{array}$ \\
\hline .712 & .508 & .502 & .298 & 2.118 \\
\hline
\end{tabular}

Source: Survey data, 2020

According to this $\mathrm{R}^{2}=0.508$ and it describes $51 \%$ of variation in employee retention is explained by the talent management functions. Durbin Watson statistics always have a value between 0 and 4 and the value is 2 , it can be identified that, there are no autocorrelation within the sample of the study. Here this value is 2.118 and its round up value equals to 2 . Hence researcher can prove that there was no "autocorrelation" in the sample.

The developed hypotheses were tested based on the outcomes of regression analysis. Results can be indicated in following table 3.

Table 3. Coefficient table

\begin{tabular}{|c|c|c|c|c|}
\hline \multirow{2}{*}{ Variable } & \multirow{2}{*}{ beta $(\beta)$} & \multirow{2}{*}{$p$ value } & \multicolumn{2}{|c|}{$95 \%$ confidence interval for $b$} \\
\hline & & & lower bound & upper bound \\
\hline constant & 1.297 & 0.00 & .984 & 1.610 \\
\hline TA & 0.578 & 0.00 & 0.480 & 0.676 \\
\hline TD & 0.380 & 0.00 & 0.376 & 0.675 \\
\hline RCS & 0.287 & 0.001 & 0.126 & 0.448 \\
\hline SP & 0.173 & 0.00 & 0.094 & 0.253 \\
\hline
\end{tabular}

Source:Survey data, 2020

According to table 3 results can be interpreted as follows.

$\mathrm{H}_{1}$ : There is a significant effect of talent acquisition on employee retention in private commercial banking sector of Western province in Sri Lanka. According to the results of regression analysis beta value was $0.578(\beta=$
0.578 ) and there is no value between lower bound (0.480) and upper bound (0.676) in confidence interval. Hence it is statistically significant at $95 \%$ confidence level $(p=0.000)$. Hence $\mathrm{H}_{0}$ is rejected since $\mathrm{r} \neq 0$ and $\mathrm{p}<$ 0.05 . Accept $H_{1}$. Finally it can be concluded that there is a significant 
positive effect of talent acquisition on employee retention.

$\mathrm{H}_{2}$ : There is a significant effect of talent development on employee retention in private commercial banking sector of Western province in Sri Lanka

According to the results of regression analysis beta value was $0.380(\beta=$ 0.380 ) and there is no value between lower bound (0.376) and upper bound (0.675) in confidence interval. Hence it is statistically significant at $95 \%$ confidence level $(p=0.000)$. Hence $\mathrm{H}_{0}$ is rejected since $\mathrm{r} \neq 0$ and $\mathrm{p}<0.05$ Accept $\mathrm{H}_{2}$.Finaly it can be concluded that there is a significant positive effect of talent development on employee retention.

$\mathrm{H}_{3}$ : There is a significant effect of rewards and compensation on employee retention in private commercial banking sector of western province in Sri Lanka. According to the results of regression analysis beta value was 0.287 ( $\beta=$ 0.287 ) and there is no value between lower bound (0.126) and upper bound (0.448) in confidence interval. Hence it is statistically significant at $95 \%$ confidence level $(\mathrm{p}=0.001)$. Hence $\mathrm{H}_{0}$ is rejected since $\mathrm{r} \neq 0$ and $\mathrm{p}<0.05$ Accept $\mathrm{H}_{3}$.Finaly it can be concluded that there is a significant positive effect of talent development on employee retention.

$\mathrm{H}_{4}$ : There is a significant effect of rewards and compensation on employee retention in private commercial banking sector of Western province in Sri Lanka According to the results of regression analysis beta value was $0.173(\beta=$ 0.173 ) and there is no value between lower bound (0.094) and upper bound (0.253) in confidence interval. Hence it is statistically significant at $95 \%$ confidence level $(\mathrm{p}=0.000)$. Hence $\mathrm{H}_{0}$ is rejected since $\mathrm{r} \neq 0$ and $\mathrm{p}<0.05$ Accept $\mathrm{H}_{4}$. Finally it can be concluded that there is a significant positive effect of succession planning on employee retention.

\section{DISCUSSION}

The main purpose of this study was to investigate the impact of talent management on employee retention. To accomplish that purpose researcher selected private commercial banking sector in Sri Lanka and study was limited to western province. The independent variable of the study is talent management and it consists with four dimensions as talent acquisition, talent development, rewards and compensation strategies and succession planning. The dependent variable of the study is employee retention. Based on the findings of the study researcher found that there is a positive impact of talent management on employee retention. In addition to that many researchers have found that there is a positive effect of talent management on employee retention.

The study done by Silvia, K. (2013) has proved that there is a positive impact of talent management on employee retention. Kigo, G. (2016) has conducted a study relating to the talent management. The study revealed that talent acquisition positively effect on employee 
retention. The researcher present study also found that the positive impact of talent acquisition on employee retention. Cheng, et al., (2017) indicated rewards and compensation strategy positively effect on employee retention and current study findings also proved that argument. Further the impact of succession planning employee retention was positive. Basit Javed \& Mohammad (2019) proved that the positive impact of succession planning on employee retention. Accordingly based on the study findings and literature, researcher can strongly prove that the positive impact of talent management and its functions on employee retention.

Further, in order to encourage talent management functions in banking sector banks need to enhance their awareness regarding their employees. To recruit talented qualified employees banks can get the support of recruitment agencies for the effective employee selection process. At the same time banks need to put more aware to recruit diversified employees rather than traditional skilled employees. As well as bank can increase their investment on training and development programs, community development programs and other employee welfare programs in order to raise employee motivation, commitment, more engagement and ultimately employee satisfaction. Satisfied employees are more productive than normal employees and they have more loyalty for the job and the organization. Accordingly satisfied employees stay longer period of time and these employees protect the employee retention of the organizations.

As well as there were some limitations throughout the whole research process and one of them was the constitution of the sample which has been used by the researcher. Respondents were not randomly selected from the large population and some respondents may not paid full attention for the study questionnaire. Apart from that confidentiality information, personal bias, tendency to give responses that are socially desirable by the participants were other common limitations.

Furthermore, future researchers can conduct their studies regarding the study area of talent management by considering other aspects such as organizational performance, job satisfaction, and employee engagement etc.

\section{CONCLUSION}

The present study was designed and conducted to investigate the impact of talent management on nonmanagerial employee retention in private commercial banking sector of Western province in Sri Lanka. Accordingly, this research finding will be helpful for whole banking sector not only for private commercial banks in western province in order to identify which aspect to talent management initiatives effects on bank's employee management. Creating better talent management procedure is a long term investment and which ensure the stability and long tern survival of the 
business organizations. Talent management address the human capital of the organizations and humans are the heart of any organizations. As well as long term survival of talented employees is the key factor of determination of organization's success. Further long term survival of employees ensure the favorable employee retention rate. Accordingly present study has focused on non-managerial employees in private commercial banks and non-managerial employees are drivers of daily operations of banks. Therefore, their satisfaction is compulsory to ensure their retention. Further it can be noted that the talent management functions are not only factor of determining employee retention and it may be affected by other several personal factors of employees and can prove that talent management functions have considerable amount of positive influence on employee retention. Accordingly based on the study findings and previous literature proved that there is a significant positive impact of talent management on employee retention. Therefore finally it can be recognized that there is a significant positive impact of talent management on nonmanagerial employee retention in private commercial banking sector of Western province in Sri Lanka.

\section{REFERENCES}

Cheng, W.L., Ling, C., Tong, K.Y., \& Li, S.W. (2017). study on the Relationship between Talent Management and
Employee Retention in

Telecommunication industry.

Cobb, A. (2008). Using Talent

Management to Drive

Competitive Advantage.

Retrieved from Hotel

Busniess Review:

http://www.hotelexecutuive.c

om

Herman, R. E \& Gioia, J.L. (2001). How to become an employer of choice. Employement relations today.

Javed, B., \& Jaffar, M. (2019). Impact of succession planning employee retention.

Kigo, S. K., \& Gachunga, D.H. (2016). Effect of Talent Management strategies on Employee Retention in the Insurance industry. The Strategic Journal of Business and Change Management, 3(2),977-1004.

Kossivi, B., Ming, Xu, Kalgora, M. (2016). Study on determining factors of emplyee retention. Open journal of social science , 4(5),261-270.

Silvia, K. (2013). Relationship between Talent Management and Employee Retention in Commercial Banks in Kenya. 
Stockly, D. (2007). Talent Management Concepts:

Definitions and explanation.

Walker, J.W. (2001). "Perspectives"

Human

resource

planning. 24

(1):6-10. 